\title{
Bloques de hormigón, análisis de la normativa UNE, ISO, en comparación con otras normas internacionales
}

\author{
Concrete blocks. Analysis of UNE, ISO en \\ standards and comparison with other \\ international standards
}

\begin{abstract}
RESUMEN
En este trabajo se pretende describir la reciente aprobada normativa UNE, analizando sistemáticamente las principales prescripciones contempladas y los valores considerados para cada una de ellas, así como los proyectos de Norma ISO, y EN sobre bloques de hormigón. Asimismo se intenta situar la normativa UNE en al ámbito internacional, haciendo un análisis comparativo con una representación de Normas de distintas regiones geográficas del mundo, determinando sus analogías y diferencias.
\end{abstract}

\begin{abstract}
This paper attempts to describe the recently approved UNE standards through a systematic analysis of the main specifications therein contained and the values considered for each of them, as well as the drafts for ISO and EN concrete block standards. Furthermore, the study tries to place the set of ISO standards in the international environment through a comparative analysis against a representative sample of the standards prevailing in various geographical regions of the globe to determine the analogies and differences among them.
\end{abstract}

\section{PALABRAS CLAVE:}

ALBAÑILERÍA, ANALISIS DE SISTEMAS, BLOQUE DE HORMIGÓN, MUROS DE FÁBRICA, NORMATIVA.

\section{INTRODUCCIÓN}

La experiencia internacional en construcción utilizando bloques de hormigón ha demostrado el excelente comportamiento de este sistema constructivo y su adaptabilidad a cualquier tipo de edificación. Sus propiedades tanto físicas como mecánicas, su versatilidad, unida a su coste de fabricación favorecen su utilización; a la vez que su facilidad para cambiar formas, colores y texturas lo hacen adaptable a cualquier requerimiento, especialmente a las construcciones en serie de baja altura. Es en este tipo edificatorio donde todas las ventajas del sistema se muestran más ostensibles, al permitir una economía en materiales y mano de obra que dificilmente puede alcanzarse con otros sistemas constructivos.
KEY WORDS:

MASONRY, SYSTEM ANALYSIS, CONCRETE BLOCKS, MASONRY WALLS, STANDARDS.

\section{INTRODUCTION}

The international experience in concrete block construction has proven the excellent behaviour of this construction system and its adaptability to any type of construction. The physical and mechanical properties of the material, its versatility, together with low manufacturing costs, favour its use whilst its ease to change block shape, colour and texture makes the material very adaptable to any requirements, particularly low rise repetitive buildings. It is in this construction type where all the advantages of the system become more ostensible, as it permits material and labour economies which can hardly be reached by other systems. 
Debido a las ventajas mencionadas, y a que la construcción de viviendas adosadas en España ocupa un volumen realmente importante de la actual actividad edificatoria, se planteó la necesidad de normalizar este sistema, procediendo a la elaboración de las Normas UNE correspondientes para, de esta manera, equiparar la normativa española a la internacional sobre el tema.

En este trabajo se estudia la normativa española sobre bloques de hormigón, realizando un análisis descriptivo de sus prescripciones, así como las propuestas de Normas ISO y EN, organizaciones de normalización en las que participa España. Asimismo, se compara la Norma UNE con una muestra de 10 Normas internacionales, en lo referente a prescripciones y valores especificados para, a la vez que se conoce lo que en este sentido se ha realizado en otros países, confrontar las diversas soluciones dadas a cada cuestión.

\section{DOCUMENTOS NORMATIVOS ISO Y EN SOBRE BLOQUES DE HORMIGÓN}

La ISO es la Organización Internacional de Normalización y en ella participan, en distinto grado, 90 países del mundo. Su objetivo es promover el desarrollo de una normativa internacional, con el fin de facilitar el intercambio de bienes y servicios, y la cooperación en actividades intelectuales, tecnológicas y económicas entre los países miembros. Los resultados de los trabajos técnicos de ISO son publicados en forma de Guías y de Normas Internacionales, elaboradas por comités técnicos (TC) con una numeración que corresponde a un ámbito temático, desarrollándose por grupos de trabajo específicos, y para cuya publicación es necesario que el proyecto de Norma se apruebe por la mayoría de los países miembros.

Las Normas ISO sobre bloques de hormigón están siendo en este momento desarrolladas por el ISO/TC 179 MASONRY, que elabora las siguientes DP:

- ISO DP 9652 -1 MASONRY - Part 1: Unreinforced masonry designed by calculation.

- ISO DP 9652 -2 MASONRY - Part 2: Masonry designed by simple rules.

- ISO DP 9652 -4 MASONRY - Part 4: Test methods.

- ISO DP 9652 -5 MASONRY - Part 5: Definitions.
Owing to the above advantages, and to the fact that the construction of row or town houses reaches a really considerables volume in the current Spanish construction activity, the need to standardise the system was stated proceeding to elaboration of UNE standards and in this way to place Spanish rules on the matter at the same level as the international standards.

This paper studies the Spanish concrete block standard through a descriptive analysis of its requirements, as well as the standard drafts ISO and EN, standard organisations of which Spain is a part. It also compares the UNE standard with a sample of 10 international standards in respect of requirements and values with the purpose of being aware of what has been done in other countries and at the same time contrasting the different solutions given to each problem.

\section{CONCRETE BLOCK ISO Y REGULATORY DOCUMENTS}

ISO is the International Standard Organisation where 90 countries participate in different degrees. Its objetive is to promote the development of international standards with a wiew to facilitate the exchange of goods and services and the cooperation in intellectual, technological and economic activities among member countries. The results of the technical work by ISO are published in the form of International Guidelines and Standards, prepared by technical committees (TC) numbered according to the subject and developed by specific task groups. A majority vote of the member countries is required to publish a document.

ISO concrete block standards are presently being developed by ISO/TC 179 MASONRY whic works on the following DP:

- ISO DP 9652-1 MASONRY. Part 1: Unreinforced Masonry Designed by Calculation.

- ISO DP 9652-2 MASONRY. Part 2: Masonry Designed by Simple Rules.

- ISO DP 9652-4 MASONRY. Part 4: Test Methods.

- ISO DP 9652-5 MASONRY. Part 5: Definitions. 
EI CEN es el Comité Europeo de Normalización, en el que participan, en distinto grado, instituciones de normalización europeas pertenecientes a los países comunitarios y a otros países de la asociación europea del libre cambio. En el contexto de las actividades que actualmente desarrolla la Comunidad Económica Europea, en orden a la implantación del mercado único europeo con la supresión de barreras técnicas a los intercambios, el CEN tiene como objetivo la elaboración de Normas armonizadas europeas EN que favorezcan el libre mercado de bienes y servicios.

La elaboración de las Normas EN se realiza al igual que las ISO, a través de comités técnicos (TC) y dentro de ellos por diversos grupos de trabajo, tendiendo a coincidir básicamente con el contenido de las Normas ISO.

Las Normas EN sobre bloques de hormigón son abordadas en este momento por el CEN/ TC 125 MASONRY, cuyo task group 3 Concrete units, elabora el documento normativo que establece los materiales, manufactura y propiedades físicas y mecánicas que deben cumplir los bloques de hormigón normales y cara vista, con nomenclatura:

- CEN/ TC 125/ WG 1/ TG 3.

El uso estructural de la albañilería está descrito en el Eurocode 6 "Common unified rules for masonry structures".

\section{NORMATIVA ESPAÑOLA UNE SOBRE BLOQUES DE HORMIGÓN}

La situación existente en España, en relación a este sistema constructivo, previa a la elaboración y aprobación experimental de las Normas UNE en Julio de 1989 era realmente precaria, solamente existían las Normas Tecnológicas NTE-EFB y NTE-FFB. Era evidente la necesidad de crear un cuerpo de normas que, cubriendo el vacío legal existente, equiparara este sistema al de fábrica de ladrillo, sobre el cual ya desde 1972 existía una Norma básica de obligado cumplimiento, MV-201, y a la normativa internacional.

En este sentido se creó en el A.E.N.O.R., organismo fundado en 1986 como la entidad para desarrollar las tareas de normalización y certificación en España, el comité técnico 41, compuesto por representantes de ministerios, colegios profesionales, asociaciones internacionales especializadas en trabajos de normalización y otras organizaciones
CEN is the European Standards Committe where different European standard organisation, both from EEC and EFTA member countries, participate in different degrees. Within the scope of the activities presently undertaken by the European Economic Community to implement the European single market by eliminating technical trade barriers, the objective of CEN is to prepare a set of harmonised European EN standards favouring a gree goods and services market.

EN standards are prepared, similarly as ISO standards, by technical committees and within them by different task groups, who basically try to match the contents of ISO standards.

The EN concrete block standard is now being developed by CEN/TC 125 MASONRY whose task group 3 Concrete Units is writing a regulatory document establishing the material, manufacture and physical/mechanical properties to be met by normal and exposed concrete blocks with the following terminology:

\section{- CEN/TC 125 1/TG 3}

The structural use of masonry is dscribed in Eurocode 6 "Common Unified Rules for Masonry Structures".

\section{SPANISH CONCRETE BLOCK STANDARDS}

The situation prevailing in Spain before the preparation and experimental approval of UNE standards in July 1989 was certainly precarlous as only the NTE-EFB and NTE-FFB Technological Standards existed. The need was evident to create a body of rules to cover the existing legal void putting this system at the same level as brick construction, for which there was since 1972 the MV-201 mandatory basic rule, and to the international set of standards.

In this respect, the technical committee 41 was created within AENOR, an organisation founded in 1986 as the agency charged with standardisation and certification activities in Spain. This technical committe 41, formed by representatives of several Ministries, professional associations and other concerned organisations, has developed this set of 
interesadas, que ha desarrollado esta normativa dentro del conjunto de Normas UNE.

De esta manera se ha elaborado la Norma UNE 41166, que clasifica por el tipo, categoría, grado y/o uso, designa y fija las prescripciones que deben cumplir los bloques de hormigón y los materiales componentes, y las Normas UNE (41167-41172) -ver Tabla 1- que la complementan, describiendo los métodos de ensayo a seguir para su caracterización. satandards within the ensemble of UNE Standards.

The committe has prepared the UNE 41166 standard that classifies concrete blocks by type, category, grade and/or use, designates and establishes the requirements to be met by concrete blocks and the component materials, as well as the complementing 41167 and 41172 UNE standards (see Table 1), describing the test methods to be performed for characterization.

TABLA 1 TABLE 1

Normativa .UNE referente a bloques de hormigón (UNE specifications for concrete masonry units)

\begin{tabular}{|c|l|}
\hline $\begin{array}{c}\text { NORMA UNE } \\
\text { (UNE STANDARD) }\end{array}$ & \multicolumn{1}{c|}{ TITULO (REFERENCES) } \\
\hline 41166 & $\begin{array}{l}\text { Definiciones, clasificación y características generales (Definitions, classification and general } \\
\text { characterstics) }\end{array}$ \\
\hline 41167 & $\begin{array}{l}\text { Medición de las dimensiones y comprobación de la forma (Dimensions measurement and size } \\
\text { verification) } \\
\text { Determinación de la sección bruta, sección neta e índice de macizo (Determination of gross } \\
\text { area, net area and solid index) } \\
\text { Determinación de la densidad real del hormigón (Determination of concrete density) } \\
41168\end{array} 41169$ \\
41171 & $\begin{array}{l}\text { Determinación de la absorción del agua (Determination of water absorption) } \\
\text { Determinación de la succión (Determination of suction) } \\
\text { Determinación de la resistencia a compresión (Determination of compressive strength) }\end{array}$ \\
\hline
\end{tabular}

Las exigencias de la normativa UNE, como se puede apreciar en la Tabla 2, comprende una amplia gama de prescripciones: características de aspecto, geométricas (dimensiones modulares, tolerancias dimensionales, espesores, etc.), físicas (absorción, succión), mecánicas, térmicas, acústicas y de resistencia al fuego.

Basándose en estas Normas UNE, por Orden de 4 de Julio de 1990, se aprueba el "Pliego de prescripciones técnicas generales para la recepción de bloques de hormigón en las obras de construcción (RB-90)", que entrará en vigor a los seis meses de su publicación en el Boletín Oficial del Estado, el 11 de Julio de 1990. Tiene por objeto establecer las prescripciones técnicas que han de reunir los bloques de hormigón para su recepción en las obras de construcción, los métodos de ensayo para determinar sus características y el procedimiento general de recepción, siendo de obligatoria observancia a todas las obras de construcción, en cuya financiación participe la Administración del Estado.
The UNE standard specifications, as can be observed in Table 2, comprise a wide range of requirements: characteristics of aspect, geometric (modular dimensions, dimensional tolerances, thicknesses, etc.) physical (absorption, suction), mechanical, thermical, accoustic and fire resistence.

Based on these UNE standards, the Ministerial Order of 4 July, 1990 approved the "Sheet of General Technical Specifications for the Acceptance of Concrete Blocks in Construction works (RB-90) that will be in force six months after its publication in the Official State Bulletin, i.e., on 11 July, 1990 The object of this document is to establish technical specifications to be met by concrete blocks delivered in construction works, the test methods to determine their characteristics and the general reception procedure, mandatory in any construction project financed in whole or in part by the State. 
TABLA 2 TABLE 2

Tipos y especificaciones de bloques de hormigón según UNE 41166 (UNE 41166 types and specifications of concrete blocks)

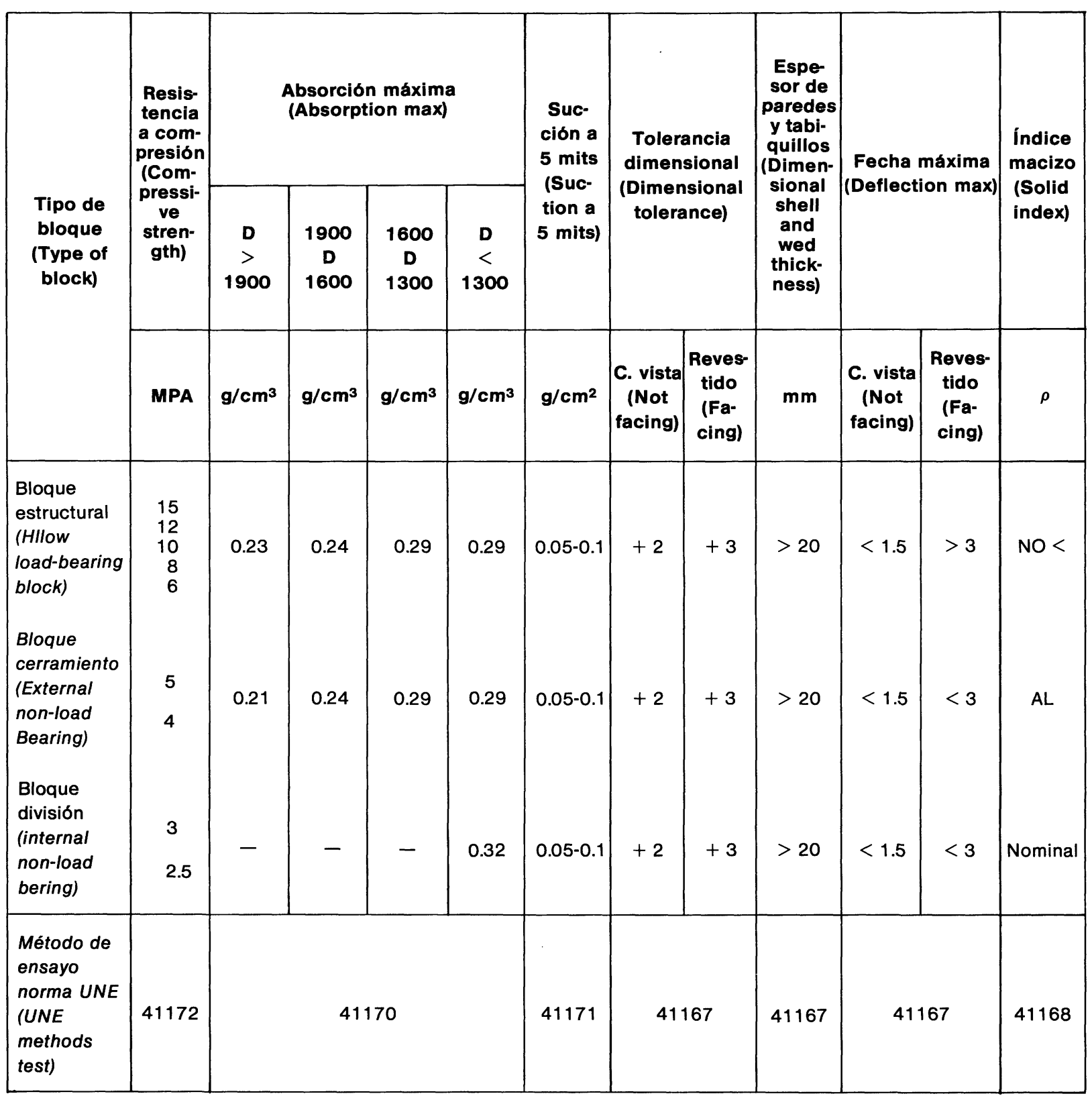

\section{COMPARACIÓN DE LA NORMA UNE 41166 Y LA NORMATIVA INTERNACIONAL}

El objeto principal de este apartado es comparar las prescripciones fundamentales de la Norma UNE así como de sus valores especificados, determinando analogías y diferencias con una muestra de Normas de otros países sobre el tema.

El análisis de las prescripciones, así como de sus valores seleccionados, se realiza sobre la documentación constitutiva de 10 Normas del

\section{COMPARISON BETWEEN UNE 41166 STANDARD AND INTERNATIONAL STANDARDS}

The main object of this section is to compare the basic specifications of the UNE standard and its specific values, determining the analogies and differences against a sampling of standards in use in other countries on the same subject.

Specifications, as well s selected values, are analysed on the basis of the documentation of 10 standards representative of several parts 
ámbito internacional, representativas de varias partes del mundo - ver Tabla 3-: América del Norte (U.S.A. - ASTM y Canada- CSA), América del Sur (Argentina -IRAM y Colombia - ICOMTEC), Europa (Francia -NF y Reino Unido- BS), España (NTE EFB, FFB y UNE) y la todavía en fase de elaboración EN. Comparando las prescripciones principales a fin de mostrar, lo más objetivamente posible, las características de la normativa: prescripciones físicas y mecánicas. of the world, see Table 3: North America (USA-ASTM and Canada-CSA), South America (Argentina-IRAM and Colombia-ICOMTEC), Europe (France-NF and the UK-BS), Spain (NTE, FFB and UNE) and the EN standard now in the preparation stage. A comparison of main specifications is made with the purpose of showing in the most objective fashion possible, the characteristics of the standards: physical and mechanical requirements.

\section{TABLA 3 TABLE 3}

Comparación norma UNE con normativa nacional de otros países (UNE standard comparation with othercontrees rationaz standards)

\begin{tabular}{|l|l|l|l|l|}
\hline $\begin{array}{c}\text { Organismo de } \\
\text { normalización } \\
\text { (País) } \\
\text { [Standarization } \\
\text { organism u } \\
\text { (country)] }\end{array}$ & Normas nacionales sobre bloques de hormigón (Concrete blocks national standards) \\
\hline U.S.A (USA) & ASTM-C 90 & ASTM-C - 129 & ASTM-C - 145 & \\
\hline Canadá (Canada) & CSA - 165-1 & CSA - 251 & NF-P - 14-304 & NF-P - 14-402 \\
\hline Francia (France) & NF-P - 14-101 & NF-P - 14-301 & BS - 6073-2 & \\
\hline Reino Unido (U.K) & BS - 6073 & BS - 6073-1 & & \\
\hline Argentina (Argentina) & IRAM - 11561 & & & UNE - 41172 \\
\hline Colombia (Colombia) & ICONTEC - 247 & & UNE - 41171 & \\
\hline España (Spain) & UNE - 41166 & UNE - 41170 & & \\
\hline España (Spain) & NTE - EFB & NTE - FFB & & \\
\hline CEN (CEN) & CEN/TC121/WG1 & & & \\
\hline
\end{tabular}

Con objeto de sistematizar el trabajo se enumeran estas prescripciones, de la manera que a continuación se indica:

\section{ABSORCIÓN}

Índice que representa el grado de compacidad o porosidad del hormigón. Es una prescripción que se incluye en la casi totalidad de la normativa estudiada, con un tratamiento diferente en los diversos grupos analizados.

Mientras un $40 \%$ de las Normas consultadas (ASTM, UNE, CSA e INCOMTEC) -ver gráficos 1 y 2 - fija la absorción en un porcentaje que varía en función de la densidad del hormigón constitutivo de los bloques, con un rango de valores de 10 a $22 \%$, un $30 \%$ de la normativa (IRAM, NTE) la fija exclusivamente en un valor
The relevant specifications are listed below in order to present this work in a systematic fashion.

\section{ABSORPTION}

This criterion represents the level of compaction or porosity of the concrete. This is a specification found in most standards studied, but differently treated in the several groups investigated.

$40 \%$ of the studied standards (ASTM, UNE, CSA, ICOMTEC), see graphics 1 and 2, establish absorption at a variable percentage value in terms of the density of the concrete used in the blocks within a $10 \%$ to $22 \%$ range of values, another $30 \%$ of the standards (IRAM, NTE) establish a single value of $\simeq 10 \%$ 
único, $\simeq 10 \%$. El restante $20 \%$ de las Normas no la comtempla entre sus prescripciones.

Está previsto, con un valor aún sin determinar, la inclusión de prescripciones sobre la absorción en la normativa europea EN. and the remaining $20 \%$ do not include absorption in their specifications. It is expected that European standard EN will include an absorption specification at a yet unknown value.
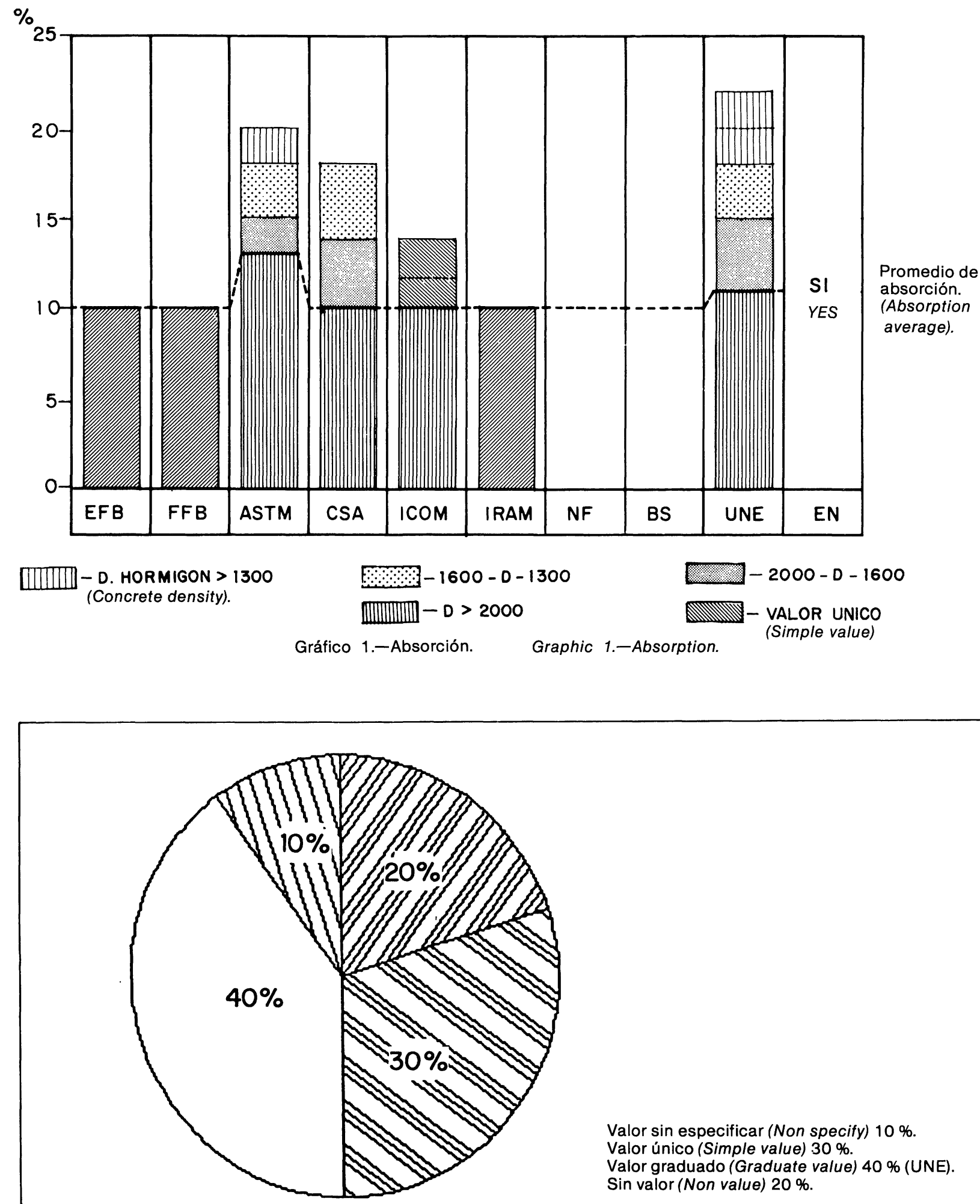

Valor sin especificar (Non specify) $10 \%$. Valor único (Simple value) $30 \%$

Valor graduado (Graduate value) $40 \%$ (UNE). Sin valor (Non value) $20 \%$.

Gráfico 2.-Absorción. Número de normas 10.

Graphic 2.-Absorption. Standards number 10. 
Existe otra forma de expresar el concepto de absorción de los bloques, conocido en América por IRA (Initial Rate of Apsortion) y en España por Succión, es un índice que la mayoría - ver gráfico 3-, el $80 \%$ de la normativa analizada, no recoge entre sus prescripciones. Está contemplada solamente en la Norma UNE con un valor de $0,05-0,10 \mathrm{~g} / \mathrm{cm}^{2}$ y en el proyecto de Norma europea $E N$, con un valor aún sin especificar.
There is another way of expressing the concept of block absorption, known in America as IRA (Initial Rate of Absorption) and in Spain as suction. This is a value that a majority of standards, $80 \%$, see graphic 3, do not contemplate in their specifications. Only the UNE standard considers this with a $0.05-0.10 \mathrm{~g} / \mathrm{cm}^{2}$ value, as also does the European EN standard, at a still unspecified value.

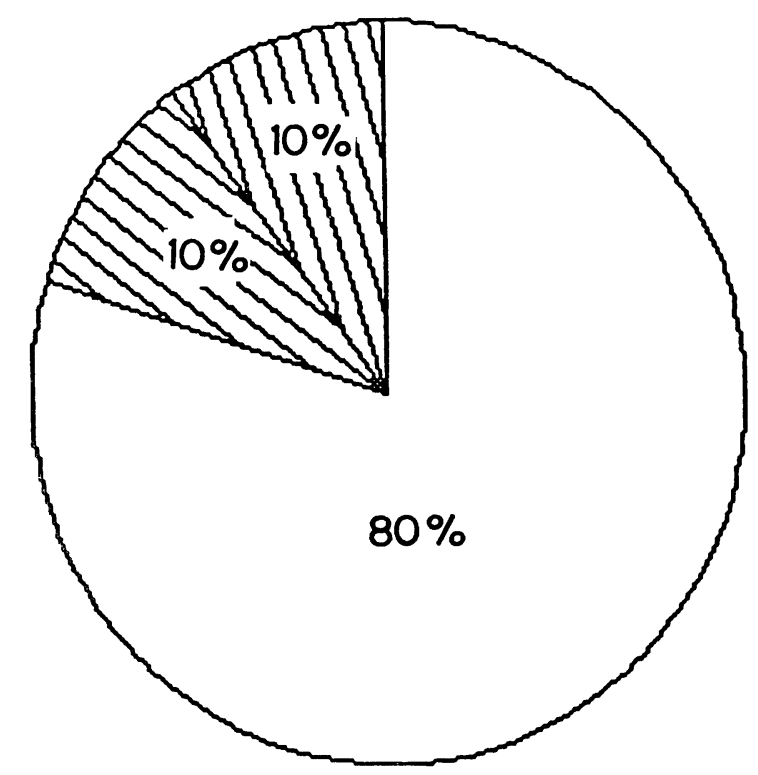

Valor sin especificar (Non specify value) $10 \%$. Valor graduado (Graduate value) $10 \%$ (UNE). Sin valor (Non value) $80 \%$

\section{RESISTENCIA A COMPRESIÓN}

En general, se observa la presencia de prescripciones sobre la resistencia a compresión referida a la sección bruta del bloque, en todas las Normas consultadas (100\%), entendiendo aquéllas como un índice que proporciona una medida de la capacidad de la albañilería para resistir las diferentes cargas con un conveniente factor de seguridad, y que determina, junto a la absorción y la succión, las condiciones de durabilidad del bloque de hormigón y su posibilidad de ser usado en los muros exteriores cara vista.

El tratamiento que la normativa analizada realiza de esta prescripción - gráficos 4 y 5es muy diverso, por lo cual se hace necesario analizarlo por separado:

\section{Resistencia en función del uso del bloque}

Un $50 \%$ de la normativa analizada (NTE,

\section{COMPRESIVE STRENGTH}

It was generally observed in all standards investigated (100 \%) the presence of compressive strength specifications refered to a gross block cross-section; this being understood as a value providing a measurement of the ability of the masonry to support loads with a reasonable safety factor and used to determine, together with absorption and suction, the conditions of durability of the concrete block and the possibility of using it in exposed external walls.

The treatment of this specification is highly varied in the examined standards, see graphics 4,5 this fact making it necessary to study each standard separately:

1. Strength in terms of block usage

$50 \%$ of the standards researched (NTE, 
IRAM, ICOMTEC, UNE) fija un límite inferior para la resistencia a compresión sobre la sección bruta del bloque de $35-40 \mathrm{kp} / \mathrm{cm}^{2}$ para muros no portantes o de cerramiento y de $55-60 \mathrm{kp} / \mathrm{cm}^{2}$ para su uso en muros estructurales.
ICOMTEC, UNE) stablish a inferior limit for the compressive strength on the block gross cross-section of $35-40 \mathrm{kp} / \mathrm{cm}^{2}$ for non-load carrying walls or perimetral walls and $55-60 \mathrm{kp} / \mathrm{cm}^{2}$ for structural walls.
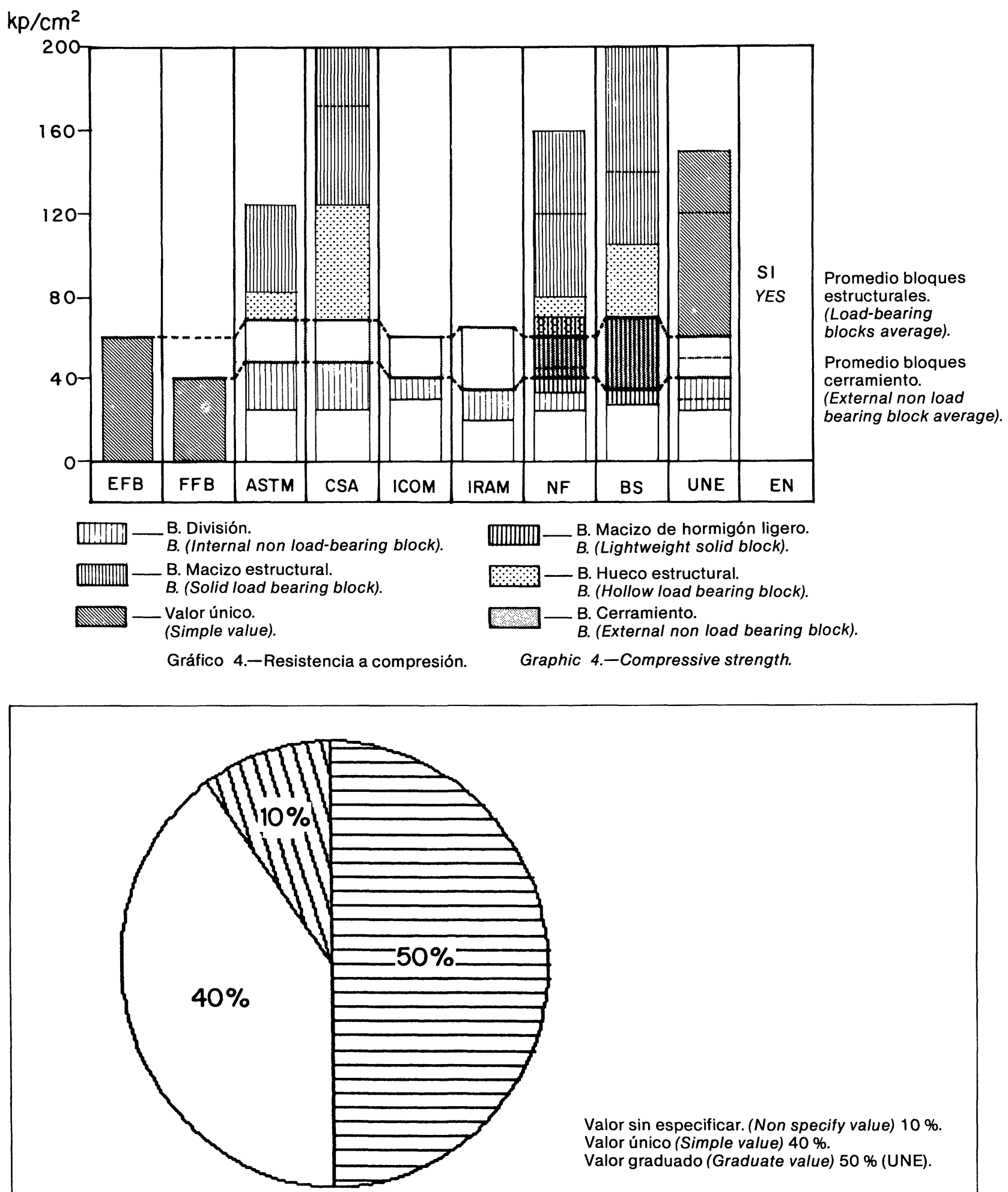

Valor sin especificar. (Non specify value) $10 \%$ Valor único (Simple value) $40 \%$.

Valor graduado (Graduate value) $50 \%$ (UNE).

Gráfico 5.-Resistencia a compresión. Número de normas 10 . 


\section{Resistencia en función del tipo de bloque}

Un $40 \%$ de la normativa consultada (ASTM, CAS, NF y BS) fija la resistencia a compresión en función del tipo de bloque clasificado, según su índice de macizo, en este sentido:

- Bloque macizo, con un índice $\rho>0,80$ debe tener una resistencia mínima a compresión de $80 \mathrm{kp} / \mathrm{cm}^{2}$ para su uso en muros estructurales.

- Bloque hueco, con un índice de macizo de $0,80>\rho>0,25$ debe tener una resistencia mínima a compresión de $60 \mathrm{kp} / \mathrm{cm}^{2}$ para muros estructurales.

\section{Resistencia en función de la densidad del hormigón}

Es una clasificación utilizada por un $20 \%$ de la normativa analizada (BS y NF), y que de alguna manera se sobrepone a la clasificación, en función del índice de macizo, en este sentido:

- Bloques de hormigón ligero, $\delta<1.700$ $\mathrm{g} / \mathrm{cm}^{3}$ deben tener una resistencia entre $25-40 \mathrm{kp} / \mathrm{cm}^{2}$ cuando son huecos y $35-70$ $\mathrm{kp} / \mathrm{cm}^{2}$ cuando son macizos.

- Bloques de hormigón normal, $\delta>1.700$ $\mathrm{g} / \mathrm{cm}^{3}$ deben tener una resistencia para uso estructural de $40-80 \mathrm{kp} / \mathrm{cm}^{2}$ cuando son huecos, y por encima de $80 \mathrm{kp} / \mathrm{cm}^{2}$ cuando son macizos.

En lo referente a la normativa EN, se tiene previsto dentro de sus prescripciones la inclusión de prescripciones sobre la resistencia de los bloques, con un valor aún sin especificar

\section{CONTENIDO DE HUMEDAD}

Índice que proporciona una medida de las condiciones del bloque para su utilización y, debido a su variación, es el principal causante de las grietas que aparecen en los muros. El contenido de humedad ideal de los bloques es aproximarse al valor de la humedad promedio del ambiente en que se van a utilizar.

Esta prescripción está contemplada en un $40 \%$ de la normativa analizada - gráficos 6 y 7-solamente en las Normas del ámbito americano que lo fijan en un porcentaje de la absorción máxima del bloque, con un tratamiento diferente en Norte y Sur.

\section{Strength in terms of block type}

$40 \%$ of the standards studied (ASTM, CAS, $N F, B S)$, establish compressive strength at a function of the block type classified by solid volume, as follows:

Solid block, with a solid proportion $\rho \geq 0.80$ to have a minimum compressive strength of $80 \mathrm{kp} / \mathrm{cm}^{2}$ when used in structural walls.

Hollow block, with a solid proportion of $0.8 \geq \rho \geq 0.25$ to have a minimum compressive strength of $60 \mathrm{kp} / \mathrm{cm}^{2}$ when used in structural walls.

\section{Strength in terms of concrete density $\delta$}

This classification is used in $20 \%$ of the standards studied (BS, NF) and, somehow, overlaps the classification based on the solid proportion, viz:

Light concrete blocks, $\delta \leq 1.700 \mathrm{~g} / \mathrm{cm}^{3}$, to have a $25-40 \mathrm{kp} / \mathrm{cm}^{2}$ strength for hollow blocks and $35-70 \mathrm{kp} / \mathrm{cm}^{2}$ for hollow blocks.

Standard concrete blocks, $\delta \gtrless 1.700 \mathrm{~g} / \mathrm{cm}^{3}$ for structural use, to have a $40-80 \mathrm{kp} / \mathrm{cm}^{2}$ strength for hollow blocks and higher than $80 \mathrm{kp} / \mathrm{cm}^{2}$ for solid blocks.

Regarding the EN standard, it is expected to contain among its requirements a strength specification, but the value is not yet known.

\section{MOISTURE CONTENT}

This criterion provides a measurement of the block use condition and its variations are the main cause of cracked walls. The ideal moisture content shall be near the average atmospheric humidity existing in the use area.

The requirement of maximum moisture contents by percentage is contemplated in $40 \%$ of the studied standards, graphics 6 and 7 , corresponding only to the North and South American area, but in the North is treated differently as in the South. 


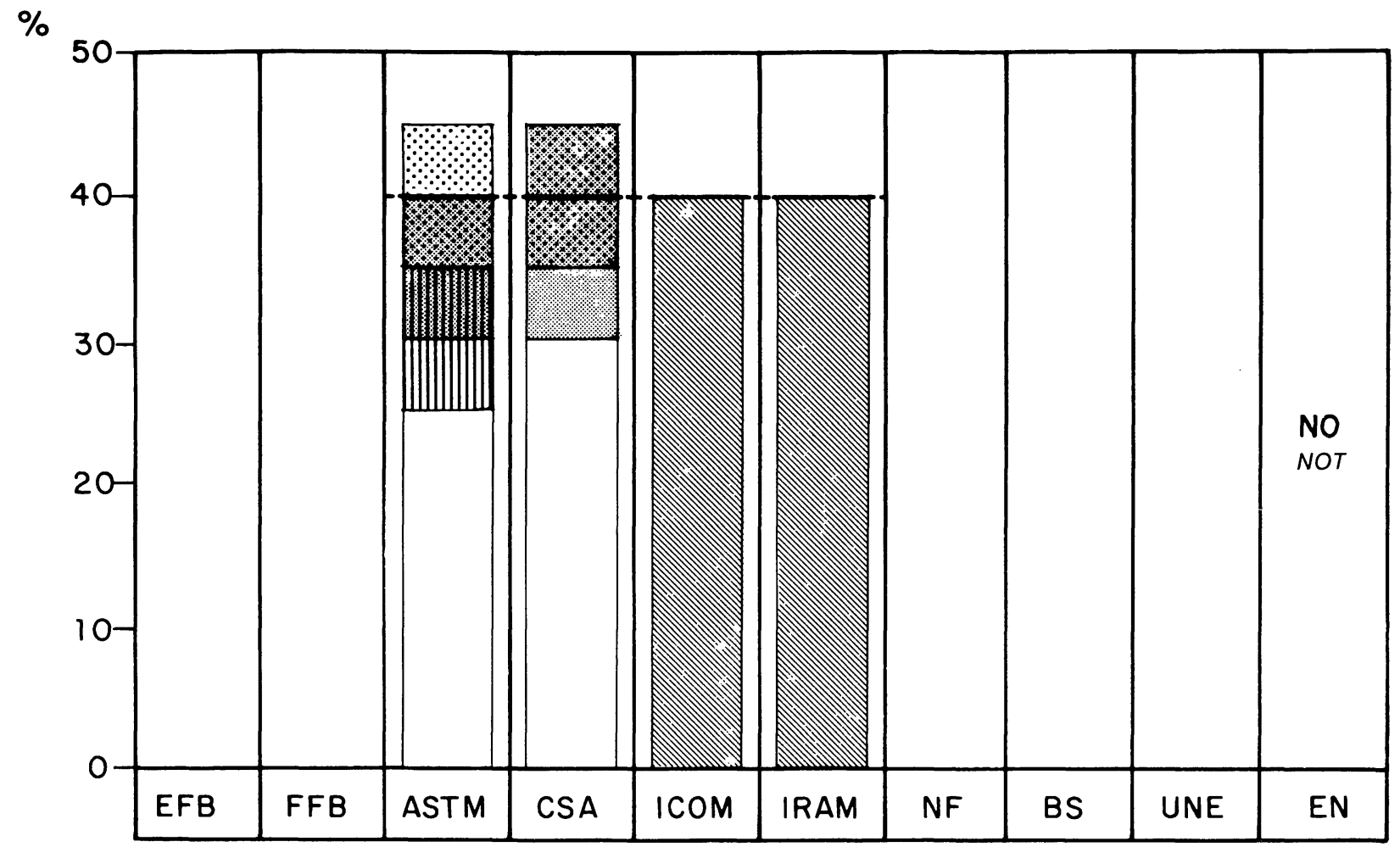

- H.R. (R.H.) > 75.

Gráfico 6.-Contenido de humedad. Graphic 6.-Moisture content.

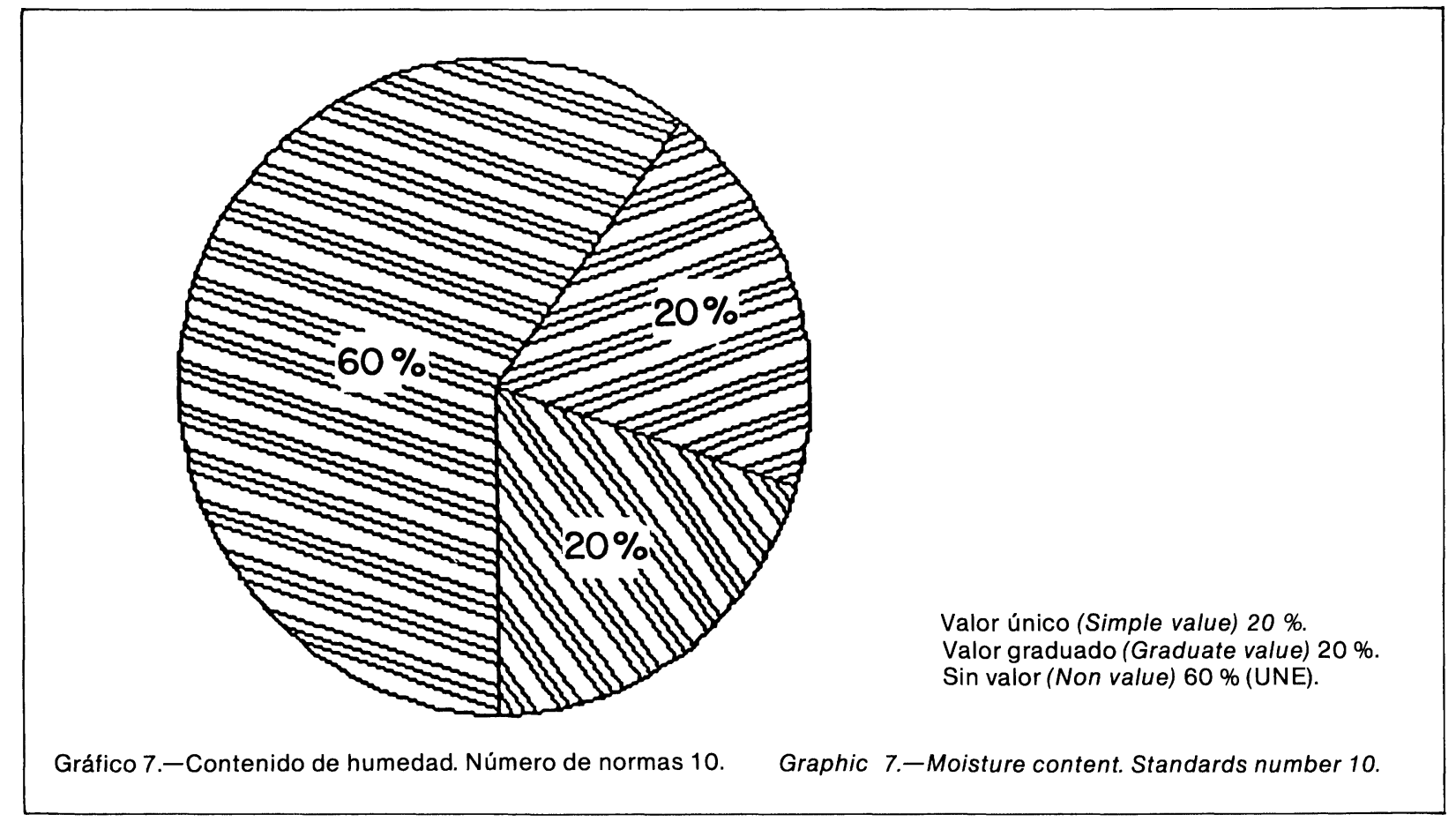


Así, mientras el $20 \%$ (ASTM, CSA) fija esta prescripción en un rango de valores entre 25-45 \% de la absorción máxima del bloque, dependiendo del grado de humedad del ambiente, el restante $20 \%$ de la normativa analizada (IRAM, ICOMTEC) fija este requerimiento en un valor único, el $40 \%$ de la absorción máxima, para cualquier condición de humedad del ambiente donde se usen. Como se puede observar, la Norma EN, al igual que las europeas analizadas, no contempla el contenido de humedad entre sus futuras prescripciones.

\section{CONTRACCIÓN LINEAL}

Índice tan fuertemente relacionado con el contenido de humedad del bloque que algunas Normas determinan esta prescripción conjuntamente con la anterior (ASTM y CSA). Está contemplada en un $40 \%$ de la normativa consultada - gráficos 8 y $9-$. Un $40 \%$ de dichas Normas (ASTM, CSA, NF y BS) lo hace en un rango de valores de 0,03-0,65 \%, ampliándose éste en la inglesa BS hasta 0,09 para hormigones ligeros.
Thus, whilst $20 \%$ (ASTM, CSA) stablesus this specification within a $25-45 \%$ value, of the maximun block absortion, the other $20 \%$ of the standards (IRAM, ICOMTEC) stablishs a single value for this parameter at $40 \%$ of maximum absortion for any the atmospheric humidity in the place of use. As can be noticed, EN standard, like the other European standards under investigated, does not include moisture content among the future specifications.

\section{LINEAR CONTRACTION}

This a parameter so strongly associated to block moisture content that some standards (ASTM, CSA) determine this specification concurrently with the one discussed above. $40 \%$ of the standards examined include this value, graphics 8 and $9.40 \%$ of such standards (ASTM, CSA, NF, BS) stablish a value range of 0.03-0.065 \% but the British standard, BS, increases the range to $0.09 \%$ in light concretes.

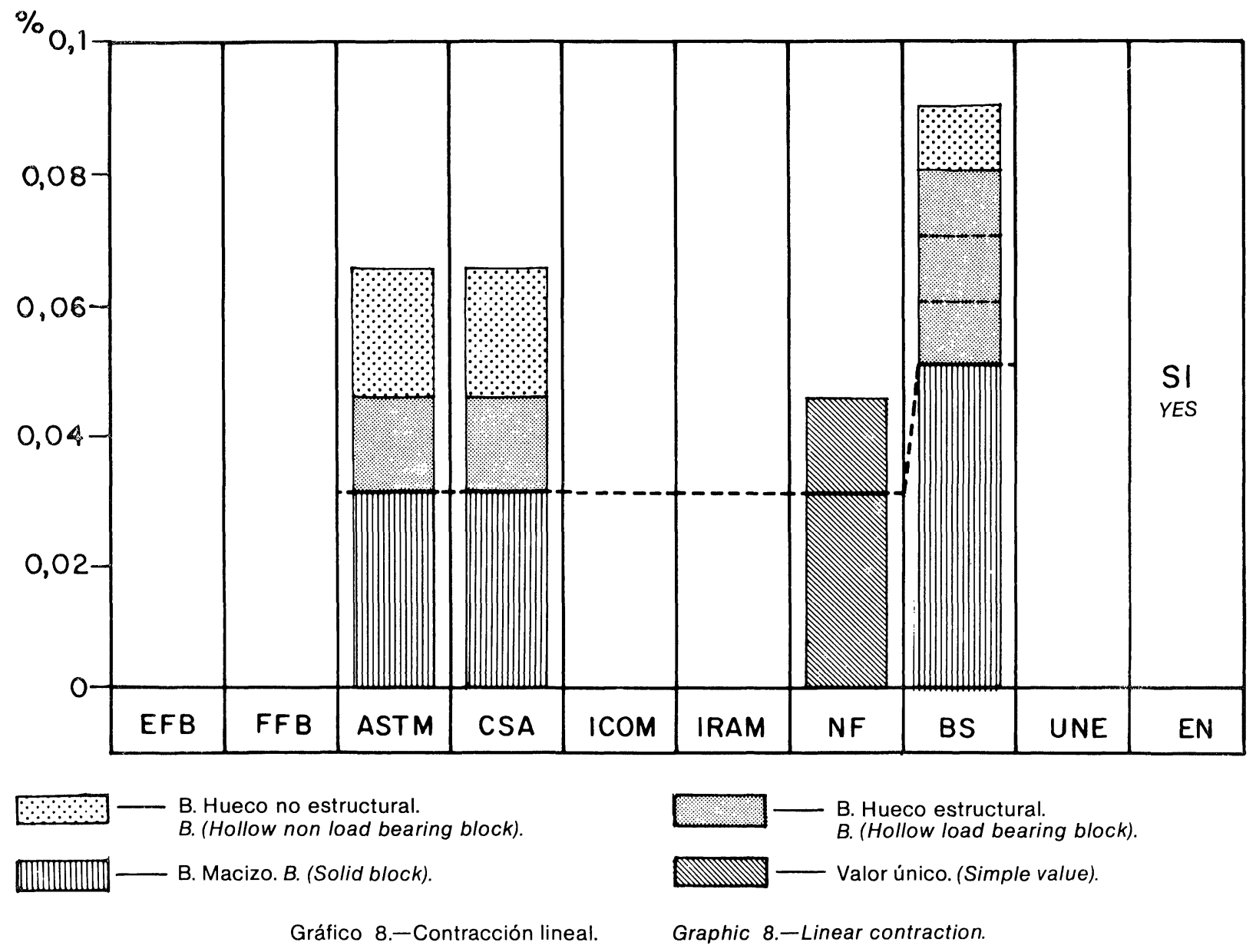




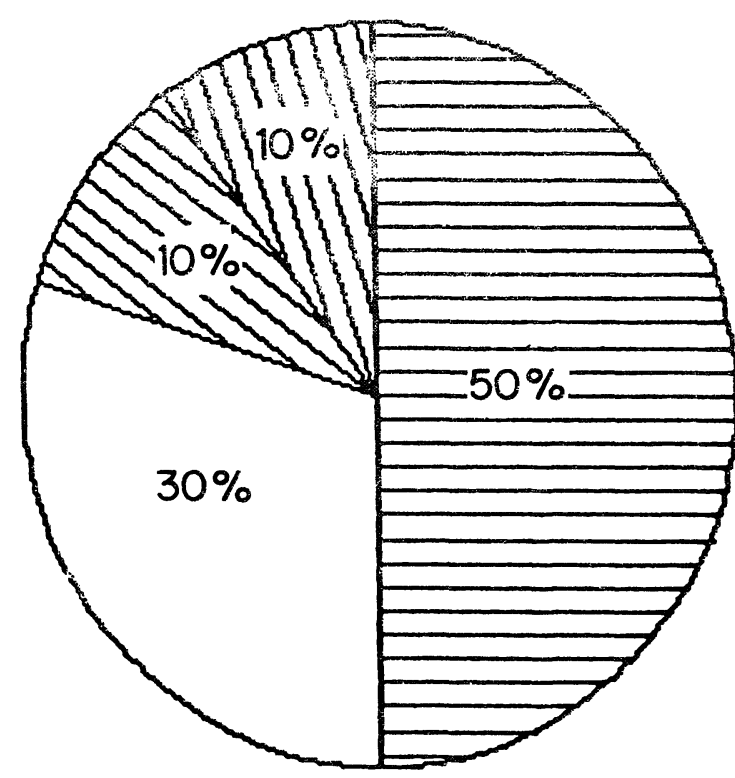

Gráfico 9.-Contracción lineal. Número de normas 10.
Valor sin especificar (Non specify value) $10 \%$ Valor único (Simple value) $10 \%$

Valor graduado (Graduate value) $30 \%$

Sin valor (Non value) 50 \% (UNE).

Graphic 9.-Linear contraction Standards number 10.

\section{ADICIÓN DE CENIZAS VOLANTES}

Observando el gráfico 10, en el que se indican las Normas que contemplan, entre sus prescripciones, ciertas adiciones que como las cenizas volantes pueden mejorar y favorecer algunas prestaciones, se puede comprobar que este requerimiento está presente en un $50 \%$ de la normativa analizada, incluyendo la

\section{FLY ASH ADDITION}

Observing graphics 10, where standards are shown that include in their specifications some additives, such as fly ash, intented to improve performance, it can be noted that this requirement is present in $50 \%$ of the standards under study, including the $E N$ standard. $40 \%$ of these standards (IRAM,

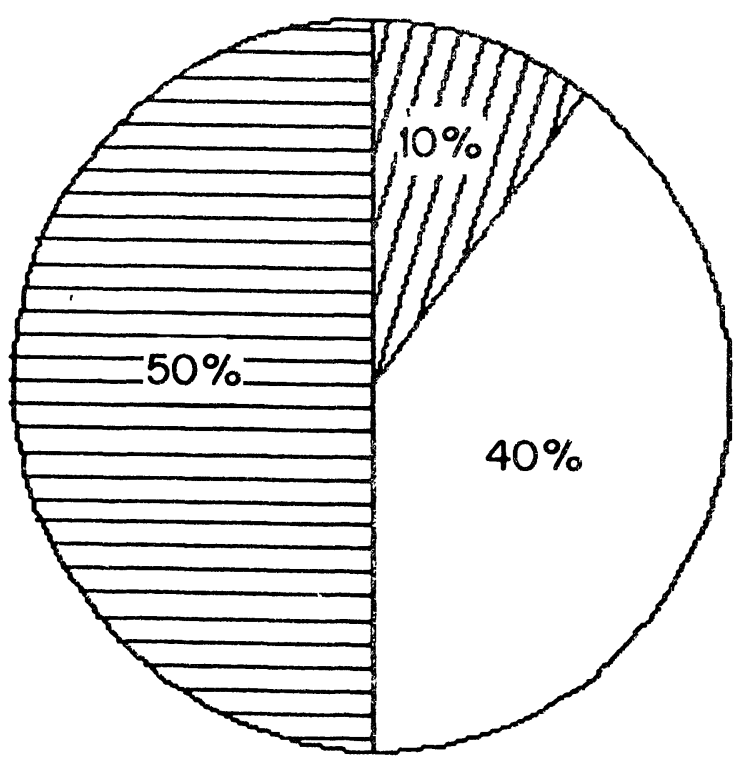

Especificada (Specifity) $50 \%$.

Sin especificar (Non specifity) $40 \%$ (UNE)

Sin contemplar (Non examined) $10 \%$.

Gráfico 10.-Adición de cenizas volantes. Número de normas 10. Graphic 10.-Fly-ash admixture. Standards number 10. 
Norma EN. Un $40 \%$ de la normativa (IRAM, ICOMTEC, NTE-FFB, UNE), aunque no directamente especificado, incluye áridos ligeros naturales y artificiales. El $10 \%$ restante NTE-EFB no contempla ésta dentro de sus prescripciones.

\section{CONCLUSIONES}

Se puede observar que el sistema constructivo, albañilería a base de bloques de hormigón, ya tiene un marco normativo adecuado dentro de la legislación española y próximamente en la comunitaria, por lo cual las entidades y personas relacionadas con el sector de la construcción tendrán que adaptarse a la terminologia y contenido de la legislación nacional, así como a las previsiones comunitarias, hasta tiempo reciente poco desarrolladas, entrando en la actualidad en una fase de gran impulso.

Se puede deducir, observando las distintas Normas consultadas, que cada una de ellas es la respuesta a una necesidad específica de un país y responde a un proceso de elaboración propio. Sin embargo, analizando cada una de las prescripciones en las diversas Normas y relacionándolas entre sí, se descubren patrones comunes generalmente coincidentes con los ámbitos geográficos seleccionados.

Se puede observar, en lo referente a la normativa UNE, que es una normativa muy completa y representa un paso adelante con respecto a la existente en España sobre bloques de hormigón con anterioridad a 1989, las NTE EFB y NTE FFB. Asimismo, la Normativa UNE se puede equiparar a la normativa internacional más avanzada, y a la existente en España sobre otros sistemas constructivos.

Sin embargo, esta normativa debería contemplar el uso de adiciones, cenizas volantes, para de esta manera estar en línea con la normativa internacional, como lo está tanto en las demás prescripciones contempladas, como en los valores considerados.
ICOMTEC, NTEA-FFB, UNE) contemplate natural and artificial light aggregates, but they are not directly specified. The remaining $10 \%$, NTE-EFB, do not include this characteristic among its prescriptions.

\section{CONCLUSIONS}

It can be seen that this constructive system, concrete block masonry, already possess an adequate standard framework in the Spanish regulations and soon in the EEC legislation also. Therefore, organisation and individuals connected to the construction industry will have to adapt to the vocabulary and contents of the national legislation as well as EEC provisions, until recently insufficiently developed, to enter in the present strong development stage.

From an examination of the different standards under study one can deduce that each of them responds to a specific need in its country and answers to that country's own manufacturing process. This notwithstanding, if each specification in the standards is carefully analysed and then all are compared, common patterns emerge generally related to the selected geographical areas.

Regarding the UNE standard, it can be observed it is a highly completory standard an represents one step ahead relative to the concrete block regulations existing in Spain prior to 1989, that is, NTE-EFB and NTE-FFB. Likewise, the UNE standard is comparable to the most advanced international standards and to that existent in Spain with respect to other construction systems.

Nevertheless, this standard should contemplate the use of additives, such as fly ashes, so as to come in line with the international standard trends, as it is already in respect of both the other specifications included and parameters considered.

\section{BIBLIOGRAFÍA}

(1) ASTM-C-90: Hollow load-bearing concrete masonry units. U.S.A.

(2) ASTM-C-129: Non load-bearing concrete masonry units. U.S.A.

(3) ASTM-C-145: Solid load-bering concrete masonry units. U.S.A.

(4) CSA-A-165-1: Standars concrete masonry units. Canadá.

(5) CSA-A-251: Quantification code for manufacture of architectural and structural precast concrete. Canadá.

(6) BS-6073: Precast concrete masonry units. Reino Unido. 
(7) BS-6073-1: Specification for precast concrete masonry units.

(8) BS-6073-2: Method for specifyng precast concrete masonry units.

(9) NF-P-14-101: Blocs en beton pour murs et cloisons. Definitions. Francia.

(10) NF-P-14-301: Blocs en beton de granulats courants pour murs et cloisons.

(11) NF-P-14-402: Blocs en beton pour murs et cloisons. Dimensions.

(12) NF-P-14-304: Blocs en beton de granulats legers pour murs et cloisons.

(13) IRAN-11561: Bloques huecos de hormigón de cemento portland. Argentina.

(14) ICOMTEC-247: Bloques huecos de hormigón para muros. Colombia.

(15) NTE-EFB: Norma Tecnológica. Estructuras de fábrica de bloques. España.

(16) NTE-FFB: Norma Tecnológica. Fachadas de fábrica de bloques. España.

(17) RB-90: Pliego de prescripciones técnicas generales para la recepción de bloques de hormigón en las obras de construcción.

(18) EUROCODE 6: Common unified rules for masonry structures.

\section{publicaciones del ICCET/CSIC}

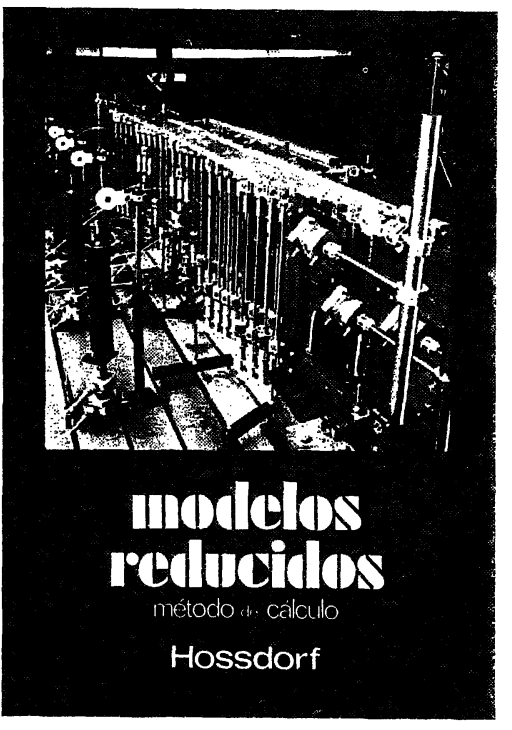

Modelos reducidos. Mótodo de cálculo

H. Hossdorf, Ingeniero Civil

La técnica de los ensayos en modelos reducidos de estructuras sufre hoy dia una decisiva metamortosis. Hasta hace poco era un medio más bien de artesania, que no siempre era tomado en serio por los académicos teorizantes para comprender el comportamiento resistente de las estructuras complejas y al que se acudió las más de las veces, como a un altimo remedio debido a sus indiscutibles insuficien cias. Sin embargo, en poco tiempo y gracias a su conexion con los ordenadores digitales, se ha trans que no puede quedar a un lado en la práctica que no puede quedar a un
diaria det Ingeniero Proyectista.

Un volumen encuadernado en cartoné plastificado con lomo de tela, de $17 \times 24 \mathrm{~cm}$, compuesto de 250 páginas, 158 figuras y fotografias.

Precios: 1.800 ptas.; \$ USA 26.00

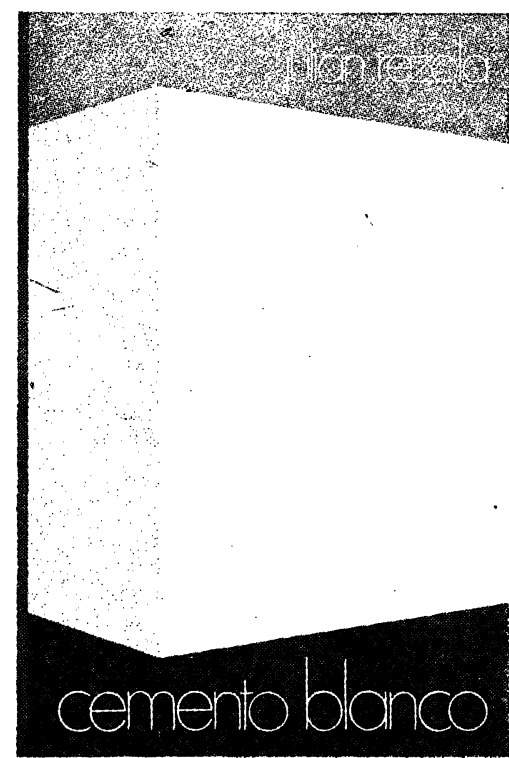

Cemento blance

Julián Rezola

Ingeniero Quimico Dipl. I. Q. S

Sabido es que existe una extensa y documentada bibliografia sobre el cemento gris: en cambio, no puede decirse lo mismo acerca del cemento portand blanco, ya que los escritos existentes se refieren tan sólo a algunas peculiaridades que le distinguen de aquél.

El autor nos ofrece sus profundos conocimientos y su larga experiencia tanto en laboratorio como

La parte descriptiva del libro se complementa con gráficos, diagramas y fotografias de gran utilidad destinados a conseguir la aplicación apropiada de este aglomerante.

Un volumen encuadernado en cartoné policerado, de $17,4 \times 24,3 \mathrm{~cm}$, compuesto de 395 páginas.

Precios: España, 1.700 ptas.; extranjero, $\$ 24.00$

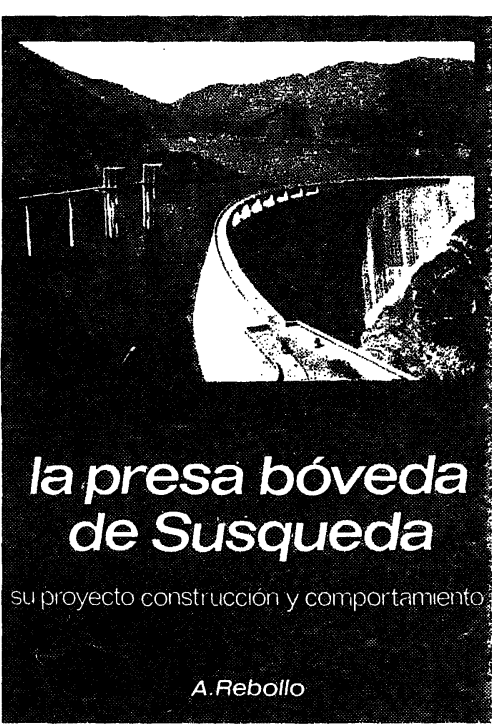

La presa bóveda de Susqueda

A. Rebollo,

Dr. Ingeniero de Caminos

El esfuerzo del constructor de presas se sitúa por su pretensión de perennidad, a contracorriente e las prencte caracte grandes presas en funcionamiento o en construccion que están envejeciendo $y$ reclaman los cuicción gerontológicos para munter y perfeccionar servicic y garantizar su inalienable pretensión su perennidad. En la medida en que todas nuevas obras, grandes o pequeñas, son portadoras de riesgos ecológicos $y$, a veces, catastróficos, que aumentan con el envejecimiento, la gerontologia de las presas es todo un emplazo. La acción adelantada de Arturo Rebollo en este terreno marca un camino a seguir para todos los que aman su propia obra con la devoción paternal que èl ha puesto en Susqueda

Un volumen encuadernado en cartoné plastificado con lomo de tela, de $18 \times 24.5 \mathrm{~cm}$, compuesto de 408 páginas, 330 figuras y totografias y 39 tablas Precios: 1.700 ptas.: extranjero, \$ USA 24.00 . 